\section{Racial and regional inequalities of dental pain in adolescents: Brazilian National Survey of School Health (PeNSE), 2009 to 2015}

\author{
Desigualdades raciais e regionais na prevalência \\ de dor de dente em adolescentes: Pesquisa \\ Nacional de Saúde do Escolar (PeNSE), \\ 2009 a 2015
}

\section{Desigualdades raciales y regionales respecto al dolor dental en adolescentes: Encuesta Nacional de Salud del Escolar (PeNSE), de 2009 a 2015}

\author{
Francine Costa 1 \\ Andrea Wendt 2 \\ Caroline Costa 3 \\ Luiz Alexandre Chisini 1 \\ Bernardo Agostini 4 \\ Rosália Neves 2 \\ Thaynã Flores 2 \\ Marcos Britto Correa 2 \\ Flávio Demarco 2
}

\begin{abstract}
The aim of the study is: (a) investigate the racial inequalities as one specific dimension that affects dental pain in Brazilian adolescents; and (b) investigate the regional variations of dental pain. This cross-sectional study used data from Brazilian National Survey of School Health (PeNSE), carried out with adolescents in 2009, 2012 and 2015. Dental pain was evaluated through the question: "Did you have dental pain in the last six months?". The main exposures were race and Brazilian regions, used to evaluate inequalities related to the outcome. Sex, age, school type and maternal education were used as covariables. The statistical significance of the trends in dental pain was tested using linear regression. The analysis was conducted in Stata 13.0 statistical package using the svy command. The standard prevalence of dental pain was $18.8 \%, 21.1 \%$ and $23.7 \%$, showing an increasing trend over time $(p<0.001)$. We observed absolute inequalities in dental pain related to race and regions. A higher prevalence was found in non-white girls of public schools and in the Northern Region. The indexes of inequalities increased in the group of black girls, related to an increase of dental pain predominantly in girls whose mothers had lower educational level. It was observed that the prevalence of dental pain in Brazilian adolescents increased over time as well as its inequalities, which remained in marginalized populations and linked to Brazilian regions.
\end{abstract}

Toothache; Adolescent; Health Inequality Monitoring; Oral Health

\author{
Correspondence \\ F. Costa \\ Universidade do Vale do Taquari. \\ Av. Avelino Talini 170, Lajeado, RS 95914-014, Brasil. \\ francinesct@gmail.com \\ 1 Universidade do Vale do Taquari, Lajeado, Brasil. \\ 2 Universidade Federal de Pelotas, Pelotas, Brasil. \\ 3 Universidade de São Paulo, São Paulo, Brasil. \\ 4 Faculdade Meridional, Passo Fundo, Brasil.
}




\section{Introduction}

Dental pain is one of the main problems in Brazilian population 1,2 with unequal distributions considering the regions of the country 3 . Previous Brazilian surveys carried out with adolescents showed a dental pain frequency ranging from $17.8 \%$ to $53.5 \%$ 1,2,4,5,6, causing, therefore, a negative impact on oral health-related quality of life 7 . The Brazilian territory is marked by deep inequalities in health resulting from historical heritage, political formation, economy and public health financing as of the implantation of Brazilian Unified National Health System (SUS) 8,9. Regarding regional variations in the oral health profile and socioeconomic conditions, Northern and Northeastern regions had more unfavorable positions than others 9 .

In addition to inequities regarding the different Brazilian regions, racism has been reported as a fundamental cause of disparities in health 10 . Racism embodies several flexible resources that advantage white individuals, whether in structural, individual and social psychological levels, which is a reflection of socio-historical process such as slavery ${ }^{10}$. The relationship between race - a socially constructed categorization that specifies rules for identifying a particular group - and health inequalities transcends the socioeconomic status 10,11 and includes power, prestige, neighborhood effects, stigmatization, discrimination, freedom and beneficial social connections that occur via multiple mechanisms regardless of socioeconomic status and promote racial differences in oral health 10. These multiples mechanisms could also influence the dental pain prevalence, and recent studies $12,13,14,15$ have theorized that discrimination can be a psychological stressing factor that underlines the racial inequalities.

Although several studies 2,5,6,16 have investigated the dental pain trends in Brazilian population, there is no study that focuses on how the racism or racial inequalities can affect dental pain in different regions. Previous studies only adjusted the analysis relating race/skin color as an indicator of socioeconomic status disadvantage or cultural traits of oral health behaviors $2,5,6,16$. Therefore, in this present study we aimed to: (a) investigate the racial inequalities - considered as a wide range of factors that precede and shape the individual's socioeconomic status - as one specific dimension that affects dental pain in Brazilian adolescents; and (b) investigate the regional variations of dental pain. Concerning race, we hypothesize that there are inequalities, which remain over time and, regarding dental pain, inequalities may differ among Brazilian regions.

\section{Methods}

This is a temporal trend study from 2009 to 2015, using data from three different aspects of the PeNSE and carried out with schoolchildren from ninth grade of middle school, enrolled in the years of 2009, 2012 and 2015. The sampled students regularly attended public and private schools located in urban and rural areas throughout the national territory. All editions of the survey were conducted by the Brazilian Institute of Geography and Statistics (IBGE) in partnership with the Brazilian Ministry of Health.

The sample size was calculated to estimate the parameters for each of the 26 State capitals and the Federal District for the first wave in 2009. The set of these State capitals and Federal District were the strata, formed by the five regions of the country (North, Northeast, South, Southeast, and Central West) plus other municipalities in each region. In order to represent the countryside of Brazil in the 2012 and 2015 editions, some cities, outside the State capitals were grouped in a stratum for each of the Federation Unities, totalizing 26 strata. The primary sampling units are represented by schools, the secondary, by classrooms, and the schoolchildren are the sample in each stratum for each city, capital and the Federal District.

The sample was randomized and equiprobabilistic for cities and capitals. One classroom was selected in schools with two ninth-grade classrooms and two classrooms were chosen in schools with three or more ninth-grade classrooms. All selected schoolchildren were invited to answer the survey questionnaire. In 2009, the data were collected with a microcomputer, the personal digital assistant (PDA). In 2012 and 2015 data collection was carried out with smartphones, in which was inserted the self-administered questionnaire. More details on the sampling process can be obtained in the publica- 
tions of Brazilian National Survey of School Health (PeNSE) 2009, 2012 and 2015 17,18,19. Considering that the 2009's edition evaluated only capital cities, excluding the other State cities, the data from all editions were delimited only for capitals for comparability purposes 17,18 .

Dental pain was evaluated through the same question in the three survey editions: "Did you have dental pain in the last six months? (excluding toothache caused by braces)". The main exposures used to evaluate inequalities related to the outcome were the Brazilian regions (North, Northeast, South, Southeast and Central West) and race/skin color, categorized according to the official classification as white, black, brown, yellow and indigenous 20 . It is important to highlight that racial classification in Brazil relies primarily on skin color or physical appearance (rather than explicitly using race, Brazilians rely on the language of skin color more often) 21 . Yet, the classification complexity is beyond skin color and much more related to how society treats racial minorities, toward racism and racial discrimination.

Maternal education was also investigated, categorized in none, incomplete middle school, complete middle school, complete high school and complete higher education, since it was the only ordinal variable collected in the study and, therefore, used to calculate complex measures of inequality as thoroughly described in the analysis below. Also, the following covariables were included in the sample description and analysis: age ( $\leq 13,14,15$ and 16 years or more), type of school (public; private) and sex (girls and boys).

The dental pain prevalence for each wave was obtained by adjusting age, considering the standard population data from the 2010 IBGE census 22. Age-adjusted statistics are used to reduce the potential confounding effect of age, when different populations are compared. Standard populations are the age distributions used as weights to create the age-adjusted rates. Two inequality indicators were demonstrated when maternal education was used as a stratifier: the Slope Index of Inequalities (SII) and the Concentration Index of Inequalities (CIX). The SII measures absolute inequality in percentage points, varying from -100 to $+100 \%$, and positive results indicate higher frequency in the adolescents whose mothers have higher educational levels or are richer, for example. The SII represents, in predicted values, the absolute difference of a health indicator between the most and least favored individuals in terms of socioeconomic matters, taking into account the entire distribution of the stratified by means of an adequate regression model. Thus, the SII is calculated as the difference, in percentage points, among the estimated values for the extreme groups of the stratification variable $17,18,19$. The CIX identifies relative inequality, varying from -1 to +1 , with positive results indicating higher outcome concentration in the adolescents whose mothers have higher educational levels, for example 23,24,25. CIX values were multiplied by 100 for better interpretation. In both measures, value 0 means total equality 23,26 . Finally, two graphs were presented to demonstrate the different SII and CIX from 2015 to 2009, considering all regions and races in the country, according to maternal education. For this, the CIX difference was plotted in the $\mathrm{x}$ axis $(|2015 \mathrm{CIZ}|-|2009 \mathrm{CI}|)$ and the SII difference, in the y axis (|2015 SI - $\mid 2009$ SIZ|). Thus, the values that are different from zero in the $\mathrm{x}$ and $\mathrm{y}$ axes indicate changes in CIX and SII from 2009 to 2015, respectively. Positive variations in the CIX and SII represent an increase in the inequalities, and negative variations mean the decreasing inequalities. Moreover, when the indicators are close to zero, the inequalities did not have variations between the periods evaluated. The trends in dental pain prevalence were tested by linear regression weighted by the minimum squares and statistical significance was defined as $\mathrm{p}$-value < 0.05. For all analyses, the statistic package Stata 13.0 (https://www.stata.com) and the command svy (survey) were used.

All PeNSE editions (2009, 2012 and 2015) were approved by the Brazilian National Research Ethics Committee, from the Brazilian National Health Council, which regulates and approves health research involving human beings, through their respective opinions: n. 11.537, n. 16.805 e n. 1.006.467. 


\section{Results}

Among the adolescents included in the study in 2009 ( $\mathrm{n}=63,411), 2012(\mathrm{n}=61,145)$ and $2015(\mathrm{n}=$ 51,192), the majority were girls at the age of 14 , from the Southeastern region, and about one-third had mothers with complete high school. As for race, in 2009, most of the adolescents self-reported as white individuals, however, in 2012 and 2015, there was a higher proportion of brown adolescents. The dental pain prevalence increased over time, showing adjusted prevalence from $18.8 \%$ (95\% confidence interval - 95\%CI: 18.4-19.1) in 2009, 21.1\% (95\%CI: 20.7-21.5) in 2012 to $23.7 \%$ (95\%CI: 23.3-24.2) in 2015. Lower prevalence was observed in white boys from private schools and in the Northeastern region (Table 1). The dental pain prevalence increased almost 1.0 percentage point (p.p.) per year $(\mathrm{p}<0.001)$.

\section{Table 1}

Frequency distribution of the sample, according to sociodemographic characteristics and dental pain in adolescents. Brazilian National Survey of School Health (PeNSE) 2009, 2012 and 2015.

\begin{tabular}{|c|c|c|c|c|c|c|}
\hline & \multicolumn{2}{|c|}{$\begin{array}{c}2009 \\
{[n=56,552]}\end{array}$} & \multicolumn{2}{|c|}{$\begin{array}{c}2012 \\
{[n=55,694]}\end{array}$} & \multicolumn{2}{|c|}{$\begin{array}{c}2015 \\
{[n=45,793]}\end{array}$} \\
\hline & $\begin{array}{c}\text { Weighted } \\
\text { (\%) }\end{array}$ & $\begin{array}{c}\text { Dental pain } \\
\%(95 \% \mathrm{CI})\end{array}$ & $\begin{array}{c}\text { Weighted } \\
(\%)\end{array}$ & $\begin{array}{c}\text { Dental pain } \\
\%(95 \% \mathrm{Cl})\end{array}$ & $\begin{array}{c}\text { Weighted } \\
(\%)\end{array}$ & $\begin{array}{l}\text { Dental pain } \\
\%(95 \% \mathrm{Cl})\end{array}$ \\
\hline \multicolumn{7}{|l|}{ Sex } \\
\hline Boys & 48.5 & $15.9(15.4-16.4)$ & 49.2 & $17.2(16.4-18.1)$ & 49.2 & $19.5(18.9-20.1)$ \\
\hline Girls & 51.5 & $21.7(21.2-22.3)$ & 50.8 & $24.3(23.7-24.9)$ & 50.8 & $28.3(27.6-29.1)$ \\
\hline \multicolumn{7}{|l|}{ Age (years) } \\
\hline 13 or younger & 21.2 & $15.5(14.4-16.6)$ & 19.0 & $18.5(17.0-20.0)$ & 20.4 & $19.1(17.5-20.7)$ \\
\hline 14 & 50.0 & $16.6(15.8-17.4)$ & 50.1 & $18.6(17.8-19.5)$ & 52.4 & $21.2(20.3-22.1)$ \\
\hline 15 & 18.6 & $19.6(18.3-20.8)$ & 19.4 & $22.9(21.5-24.2)$ & 18.5 & $26.0(24.6-27.5)$ \\
\hline 16 or older & 10.2 & $22.0(20.4-23.7)$ & 11.5 & $26.6(24.6-28.5)$ & 8.7 & $30.1(28.1-32.1)$ \\
\hline \multicolumn{7}{|l|}{ Race/Skin color } \\
\hline White & 40.1 & $17.0(15.9-18.1)$ & 37.7 & $20.1(18.8-21.5)$ & 36.5 & $21.7(20.3-23.1)$ \\
\hline Black & 13.0 & $20.3(18.5-22.1)$ & 14.2 & $24.9(22.9-27.0)$ & 13.5 & $25.7(23.7-27.8)$ \\
\hline Yellow & 3.8 & $19.6(16.6-22.9)$ & 4.5 & $20.6(17.9-23.7)$ & 5.0 & $23.6(20.4-27.0)$ \\
\hline Brown & 39.0 & $19.0(18.1-20.0)$ & 39.9 & $21.8(20.7-22.9)$ & 41.8 & $25.7(24.6-26.9)$ \\
\hline Indigenous & 4.1 & $21.7(18.8-24.8)$ & 3.7 & $23.2(19.7-27.3)$ & 3.2 & $24.4(20.9-28.3)$ \\
\hline \multicolumn{7}{|l|}{ Maternal education } \\
\hline None & 3.8 & $25.8(21.2-30.8)$ & 5.1 & $25.1(21.7-28.8)$ & 3.8 & $34.4(29.2-40.1)$ \\
\hline Incomplete middle school & 27.9 & $20.1(18.9-21.4)$ & 25.1 & $23.6(21.9-25.3)$ & 19.3 & $26.1(24.1-28.8)$ \\
\hline Complete middle school & 16.9 & $20.1(18.4-21.8)$ & 18.0 & $23.1(21.1-25.1)$ & 16.2 & $23.9(21.9-25.9)$ \\
\hline Complete high school & 31.6 & $17.1(1583-18.5)$ & 35.0 & $21.3(19.9-22.7)$ & 33.9 & $23.4(21.9-25.1)$ \\
\hline Complete higher education & 19.8 & $16.4(14.5-18.5)$ & 16.8 & $16.5(14.6-18.8)$ & 26.8 & $19.5(17.5-21.7)$ \\
\hline \multicolumn{7}{|l|}{ School } \\
\hline Public & 79.2 & $19.2(18.5-19.9)$ & 74.5 & $23.0(22.2-23.9)$ & 72.9 & $25.3(24.4-26.2)$ \\
\hline Private & 20.8 & $15.0(13.6-16.5)$ & 25.5 & $16.8(15.3-18.3)$ & 27.1 & $20.5(18.6-22.5)$ \\
\hline \multicolumn{7}{|l|}{ Region } \\
\hline North & 11.2 & $19.5(18.4-20.6)$ & 11.7 & $22.7(21.7-23.7)$ & 12.8 & $25.7(24.4-26.9)$ \\
\hline Northeast & 23.9 & $17.5(16.8-18.3)$ & 23.7 & $19.6(18.9-20.5)$ & 23.8 & $22.4(21.6-23.4)$ \\
\hline Southeast & 47.0 & $18.1(16.7-19.4)$ & 45.1 & $22.7(21.0-24.5)$ & 44.6 & $24.8(23.1-26.8)$ \\
\hline South & 6.8 & $19.6(18.1-21.2)$ & 7.2 & $20.7(19.2-22.2)$ & 6.1 & $22.4(20.6-24.1)$ \\
\hline Central West & 11.1 & $19.9(18.8-21.1)$ & 12.3 & $21.9(20.6-23.0)$ & 12.7 & $25.5(24.0-27.0)$ \\
\hline
\end{tabular}

95\%Cl: 95\% confidence interval. 
The lowest prevalence of dental pain was observed in white adolescents in the three surveys, but the highest prevalence was in indigenous adolescents in 2009, and black adolescents in 2012 and 2015. Considering the prevalence of dental pain in white and black adolescents, the inequalities from 2012 to 2015 had a slight reduction, analyzing absolute difference in percentage points (4.8p.p. in 2012 and 4.0p.p. in 2015). Regarding Brazilian regions, the absolute difference in percentage points was 2.4p.p. in 2009, 3.1p.p. in 2012 and 3.3p.p. in 2015 comparing the regions with the highest and lowest prevalence of dental pain. Within the categories of Brazilian regions, the prevalence of dental pain increased over time (Table 1). Also, adolescents whose mothers have never studied presented the highest prevalence of dental pain in the three surveys, when compared to other categories of maternal education.

Descriptive analysis on the frequency of dental pain in Brazilian regions regarding race/skin color shows that there was no significant difference between the prevalence of dental pain related to skin color within each region (Table 2).

Relative inequalities in dental pain concerning maternal education remained stable during the period (Supplementary Table S1. http://cadernos.ensp.fiocruz.br/static//arquivo/supplcsp-1086-20_8312.pdf). The CIX with negative coefficient shows that dental pain is concentrated among adolescents whose mothers had lower education. As for absolute inequalities, in 2009, 2012 and 2015, adolescents whose mothers had lower education presented prevalence of dental pain 11,7 and 15 percentage points higher than those whose mothers had higher education in the same periods. Figure 1 shows the changes in the SII and CIX, according to geographic regions of the country. It was observed that North, Northeast and Central West increased in both indicators, representing the worst context and similar to the country as a whole. On the other hand, Southeast has not reduced the SII, and South reduced both indicators. Figure 2 shows the changes in the SII and CIX, considering race between boys and girls. There was an increase of inequalities for both indicators for black girls and yellow and brown boys. On the other hand, indigenous boys reduced in both indicators.

Table 2

Prevalence of dental pain in adolescents, adjusted by a standard population, according to race/skin color and the Brazilian regions. Brazilian National Survey of School Health (PeNSE) 2009 and 2015.

\begin{tabular}{|c|c|c|c|c|c|c|c|c|c|c|}
\hline \multirow[t]{2}{*}{ Race/Skin color } & \multicolumn{2}{|c|}{ North } & \multicolumn{2}{|c|}{ Northeast } & \multicolumn{2}{|c|}{ Southeast } & \multicolumn{2}{|c|}{ South } & \multicolumn{2}{|c|}{ Central West } \\
\hline & $\begin{array}{c}\text { Weighted } \\
(\%)\end{array}$ & $95 \% \mathrm{Cl}$ & $\begin{array}{c}\text { Weighted } \\
\text { (\%) }\end{array}$ & $95 \% \mathrm{Cl}$ & $\begin{array}{c}\text { Weighted } \\
(\%)\end{array}$ & $95 \% \mathrm{Cl}$ & $\begin{array}{c}\text { Weighted } \\
(\%)\end{array}$ & $95 \% \mathrm{Cl}$ & $\begin{array}{c}\text { Weighted } \\
(\%)\end{array}$ & $95 \% \mathrm{Cl}$ \\
\hline \multicolumn{11}{|c|}{$\begin{array}{l}\text { Prevalence of dental } \\
\text { pain (2009) }\end{array}$} \\
\hline White & 18.6 & $16.6-20.8$ & 16.2 & $14.9-17.7$ & 16.2 & $14.1-18.6$ & 18.4 & $16.4-20.6$ & 18.8 & $16.8-21.0$ \\
\hline Black & 20.3 & $17.3-23.6$ & 18.8 & $16.9-20.9$ & 21.3 & $17.7-25.3$ & 19.7 & $15.7-24.3$ & 20.1 & 17.3-23.1 \\
\hline Yellow & 21.7 & $16.1-28.4$ & 21.8 & $18.1-25.9$ & 15.5 & $9.8-23.4$ & 27.9 & $18.1-40.6$ & 22.5 & $17.1-29.0$ \\
\hline Brown & 19.4 & $17.9-21.0$ & 17.7 & $16.6-18.9$ & 19.5 & $17.4-21.8$ & 22.8 & $19.1-27.0$ & 20.0 & $18.2-21.8$ \\
\hline Indigenous & 20.6 & $16.0-26.2$ & 17.8 & $14.7-21.3$ & 25.9 & $18.9-34.5$ & 20.9 & 13.9-29.9 & 24.6 & $19.0-31.2$ \\
\hline \multicolumn{11}{|c|}{$\begin{array}{l}\text { Prevalence of dental } \\
\text { pain (2015) }\end{array}$} \\
\hline White & 22.7 & $20.4-25.4$ & 20.6 & $18.9-22.4$ & 22.5 & $19.6-25.7$ & 20.7 & $18.6-23.0$ & 22.9 & $20.4-25.7$ \\
\hline Black & 29.9 & 26.3-33.7 & 23.9 & $21.8-26.3$ & 26.7 & $22.4-31.6$ & 22.4 & $17.6-28.0$ & 25.4 & $21.5-29.7$ \\
\hline Yellow & 33.6 & $27.2-40.6$ & 24.4 & $20.6-28.7$ & 18.5 & $11.4-28.6$ & 30.6 & $20.8-42.6$ & 20.3 & $15.2-26.5$ \\
\hline Brown & 25.4 & 23.8-27.1 & 23.1 & $21.8-24.4$ & 27.9 & $24.8-31.2$ & 25.7 & $21.4-30.5$ & 27.7 & $25.4-30.1$ \\
\hline Indigenous & 28.4 & $21.9-36.0$ & 22.3 & $18.4-26.7$ & 26.3 & $17.1-38.1$ & 21.7 & $13.9-32.3$ & 27.2 & $20.2-35.5$ \\
\hline
\end{tabular}

95\% Cl: 95\% confidence interval. 


\section{Figure 1}

Changes in Slope Index of Inequalities (SII) and Concentration Index of Inequalities (CIX) according to the Brazilian regions.

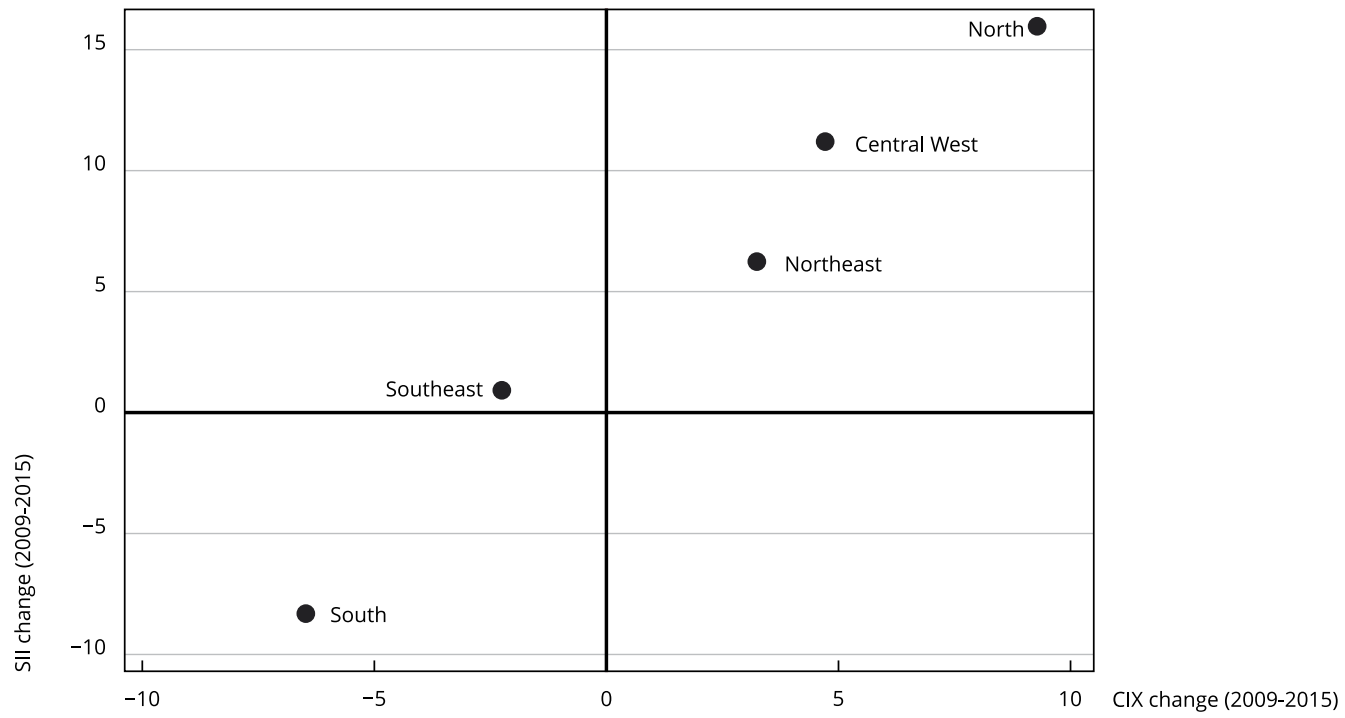

Figure 2

Changes in Slope Index of Inequalities (SII) and Concentration Index of Inequalities (CIX) according to race/skin color.

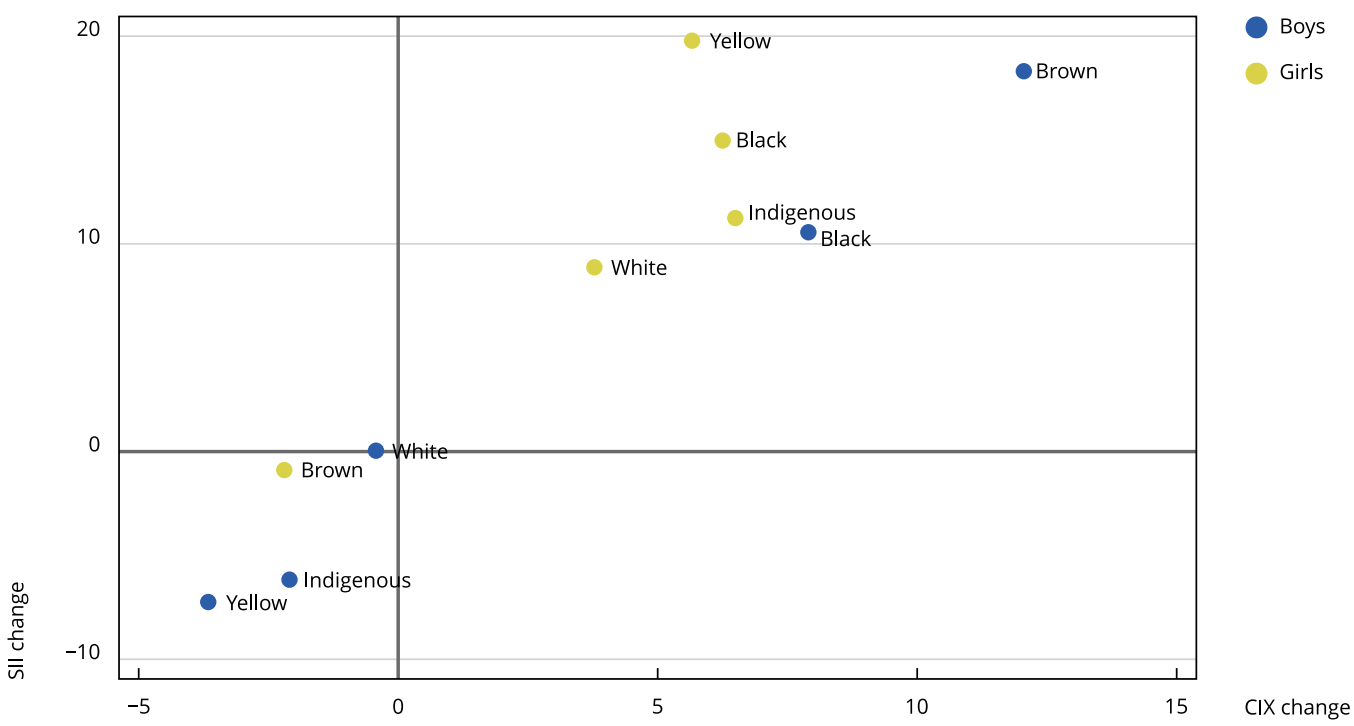




\section{Discussion}

When analyzing the inequalities according to the Brazilian regions, it was observed that the increase occurred in the Northeastern, Northern and Central Western regions. Furthermore, inequalities were observed according to sex and race. Regarding race, the inequalities were observed between and within the categories; the inequalities indexes increased in the group of black girls, at the expense of an increase of prevalence of dental pain in girls whose mothers had lower educational level, whereas the prevalence remained stable in the other categories of maternal schooling. In addition, the findings of this study showed that the prevalence of dental pain in Brazilian adolescents is increasing and there was no reduction in dental pain inequalities over time considering the whole country when maternal schooling is observed. The findings showed that both hypotheses of the study were confirmed. These results are particularly worrying, since dental pain can affect adolescents' daily activities, impairing the ability to concentrate and socially interact $7,27,28$.

This study has important strengths, which show a trend in the dental pain prevalence in Brazilian adolescents as an important subjective indicator of oral health. It also demonstrated how the indicator of dental pain responds to Brazilian adolescents over time, using data from national surveys conducted in a representative sample of schoolchildren in Brazilian capitals. Moreover, formal tests of inequalities were used to evaluate dental pain in the three moments, presenting a standard measure of changes in inequalities over the years. Hence, they could represent how much effort is still necessary to reduce inequalities. On the other hand, including only capitals and excluding out-of-school adolescents could be considered as limitations. This last limitation can be attenuated by the high prevalence of children and adolescents attending school. Data of the Brazilian National Household Sample Survey (PNAD) show that $98.4 \%$ of the population at the age of 6 to 14 years and $84.3 \%$ at the age of 15 to 17 years are in school, especially if we consider the majority of our sample is less than 15 years old. Therefore, the sample representativeness may not reflect the reality of the whole country. The income would be a more robust indicator to measure inequalities related to dental pain if we consider its association with acquisition of goods and services. However, maternal education is a proxy for socioeconomic position and it has been largely employed in epidemiological studies. In Brazil, the higher education is frequently associated with socioeconomic level. Nevertheless, the indicators may not have exactly the same meaning when some outcomes are most influenced by the level of knowledge and access to information 29,30 .

The prevalence of dental pain increases in the adolescents as a whole and this was more evident in the group with mothers having lower educational levels. The increase in dental pain is worrying, since it is often compared to the worst sensations ever experienced by the individual 31 . The increase of dental pain prevalence in marginalized populations can be a reflection of multiple mechanisms of structural racism that these populations experienced in their lives, affecting several dimensions of social and personal life, such as oral health outcomes 15 . Thus, unequal relationships between social groups shape their distribution to adverse exposures and health conditions. Discrimination in oral health services in Brazil has been highlighted in a recent study 32 and racism has also affected the dentists' decision concerning the replacement of amalgam restorations 33,34, emphasizing the structural racism that stereotypes and stigmatizes these populations 10 . In this way, it is important to deeply discuss the social-historical roots of Brazilian racism. This country was one of the main destinations for international trade of African slaves (from 16th to 19th centuries) as well as for the enslavement of the American indigenous population 35,36. Brazil was also the last country in the Americas to abolish slavery (only in 1888) 35,36. Despite no legal racial segregation regimen was established in Brazil, as occurred in the United States or South Africa, the segregation of non-white populations in Brazil is nowadays observed in political marginalization, massive incarceration of the black population ${ }^{37}$, limited access to flexible resources 10 and residential segregation 38 , which favor the lack of access to social networks, employment and higher quality of public schools 39 . Consequently, there is an increase of the socioeconomic abysm of the Brazilian society, which is considered one of most unequal all over the world 40 . Therefore, on a daily basis, racism is violently experienced and perceived by non-white people, who are deprived of several resources that can be applied to a wide range of relevant situations for health outcomes, via multiple mechanisms 10 regardless of socioeconomic status 41,42 . Based on the aforementioned assumptions, race inequalities transcend the socioeconomic 
status and involve - among others - power, freedom and prestige 10. Thus, the differences related to income are only one of them. Even if, between racial groups, differences in socioeconomic status were completely eliminated, racial health differentials would still persist as a result of racism 10 .

Reducing oral health inequalities is a global priority and, to achieve this goal, it is also necessary to reduce racial inequality. The elimination of racial inequalities in health cannot be approached if individuals adopt irrational attitudes, that is, racism could not be reduced only by education or increase of socioeconomic indicators of marginalized populations $42,43,44,45$. Considering that racial inequalities and racism are structural consequences of society, the only way to diminish them is eliminating their systemic roots through democratic or revolutionary ways, depending on the socio-political conditions of each society, according to alternative theories 43 . In other words, racism is only eliminated when there is a change in the systemic racism of society by means of democratic or revolutionary ways 43 .

Regarding to Brazilian regions, South and Southeast presented better results compared to the country as a whole, showing reduction in both absolute and relative inequality in relation to dental pain. It is possible that these inequalities are attributed to the historical, social and economic developmental process of the Northern, Northeastern and Central Western regions. Southeastern and Southern regions are richer than the others, presenting better indicators of socioeconomic development 46. Also, such situation could be a consequence of unequal implementation of important oral health programs among regions 46, justifying the variation in social, general and oral development of health standards 9 . The implementation of the Oral Health Teams in the Family Health Strategy (FHS) was questioned, since there are differences in local realities, capacity of care, human resources, financing and difficulties integrating oral health professionals to the teams of the FHS 47 . In addition, as already mentioned, actions such as water fluoridation tend to reach wealthier regions, which occurred more in the Southern and Southeastern States, where most of the country's wealth is concentrated. An effective public health measure to reduce inequalities may be responsible for deep inequalities in their implementation 46.

The prevalence of dental pain was different among Brazilian boys and girls and the inequalities increased over time. Some authors discuss similar results regarding the higher prevalence of dental caries in girls; however, this is still controversial. Many studies show that there is no difference in the prevalence of untreated dental caries among adolescents regarding sex 48,49. Moreover, it was observed that the risk factors for dental caries are variable among teenage boys and girls, which contributes to similar rates of dental caries in this age group 50. The explanations to higher prevalence of dental pain in girls in the literature are focused mainly on the theory that women are more likely to report pain while men tend to suppress signs of pain 51. However, sexism can be expressed in the adolescence in many ways from multiple sources, through stereotypes that characterize boys and girls or in other ways 52 . The literature does not really elucidate how each sex-related aspect contributes to the occurrence of oral diseases or even to the high prevalence of self-reported dental pain in girls. To date, it is possible to report the biological theories related to hormonal or even behavioral issues concerning women's sensitivity. However, in some cultures the sex differences in oral health appears to involve social and religious causes such as which children receives preference of treatment 52 . Regarding our results, the major differences found between boys and girls are alarming and instigate investigations and critical thinking that surpass what has already been discussed in the literature so that such inequality can be explained.

So, it was possible to conclude that there was no reduction in the inequalities of dental pain in adolescents in the country as a whole. Considering the regions, the analysis showed that there was an increase in inequalities in the Northern and Northeastern regions. The evolution of the indicators of dental pain and inequalities observed in Brazilian adolescents is worrying. White adolescents had lower prevalence of dental pain in all surveys compared to black adolescents. Besides, the inequalities increased in the group of black girls. Girls had higher prevalence of dental pain and the sex-related inequalities increased over time, considering the absolute difference. Reducing inequalities is still a challenge because of the need for public health coping strategies for oral health that reach the most marginalized populations or those who are sometimes neglected. 


\section{Contributors}

F. Costa contributed in the project conception, data analysis and interpretation, writing in the text, final approval of the version to be published, and was responsible for all aspects of the work in ensuring the accuracy and integrity of any part. A. Wendt contributed in the data analysis and interpretation, relevant critical reviewed of the intellectual content, final approval of the version to be published, and was responsible for all aspects of the work in ensuring the accuracy and integrity of any part. C. Costa contributed in the project conception and data interpretation, critical reviewed of the intellectual content, final approval of the version to be published, and was responsible for all aspects of the work in ensuring the accuracy and integrity of any part. L. A. Chisini, B. Agostini, R. Neves, T. Flores, M. B. Correa, and F. Demarco contributed in the data interpretation, critical review of the intellectual content, final approval of the version to be published, and were responsible for all aspects of the work in ensuring the accuracy and integrity of any part.

\section{Additional informations}

ORCID: Francine Costa (0000-0001-9558-937X); Andrea Wendt (0000-0002-4640-2254); Caroline Costa (0000-0003-0281-6890); Luiz Alexandre Chisini (0000-0002-3695-0361); Bernardo Agostini (0000-0003-4480-1873); Rosália Neves (00000001-6798-9130); Thaynã Flores (000-0003-00981681); Marcos Britto Correa (0000-0002-17973541); Flávio Demarco (0000-0003-2276-491X).

\section{Acknowledgments}

This study was conducted in a Post-Graduate Program supported by the Brazilian Graduate Studies Coordinating Board (CAPES; Finance Code 001); and by the Brazilian National Research Council (CNPq).

\section{References}

1. Freire MCM, Jordao LMR, Peres MA, Abreu M. Six-year trends in dental pain and maternal education inequalities among Brazilian adolescents. Community Dent Oral Epidemiol 2019; 47:454-60.

2. Peres MA, Peres KG, Frias AC, Antunes JL. Contextual and individual assessment of dental pain period prevalence in adolescents: a multilevel approach. BMC Oral Health 2010; 10:20.

3. Lima Saintrain M, Correa C, Saintrain S, Nuto S, Vieira-Meyer A. Brazilian adolescents' oral health trends since 1986: an epidemiological observational study. BMC Res Notes 2015; 8:554.

4. Oliveira MM, Andrade SSCS, Campos MO, Malta DC. Fatores associados à procura de serviços de saúde entre escolares brasileiros: uma análise da Pesquisa Nacional de Saúde do Escolar (PeNSE), 2012. Cad Saúde Pública 2015; 31:1603-14.

5. Santiago BM, Valenca AM, Vettore MV. Social capital and dental pain in Brazilian northeast: a multilevel cross-sectional study. BMC Oral Health 2013; 13:2.

6. Freire MCM, Leles CR, Sardinha LMV, Paludetto Junior M, Malta DC, Peres MA. Dor dentária e fatores associados em adolescentes brasileiros: a Pesquisa Nacional de Saúde do Escolar (PeNSE), Brasil, 2009. Cad Saúde Pública 2012; 28 Suppl:S133-45.

7. Schuch HS, Correa MB, Torriani DD, Demarco FF, Goettems ML. Perceived dental pain: determinants and impact on brazilian schoolchildren. J Oral Facial Pain Headache 2015; 29:168-76.

8. Souza RR. Redução das desigualdades regionais na alocação dos recursos federais para a saúde. Ciênc Saúde Colet 2003; 8:449-60.

9. Silva JV, Machado FC, Ferreira MA. Social inequalities and the oral health in Brazilian capitals. Ciênc Saúde Colet 2015; 20:2539-48.

10. Phelan J, Link B. Is racism a fundamental cause of inequalities in health? Annu Rev Sociol 2015; 41:311-30.

11. Williams D, Priest N, Anderson N. Understanding associations between race, socioeconomic status and health: patterns and prospects. Health Psychol 2016; 35:407-11.

12. Celeste RK, Goncalves LG, Faerstein E, Bastos JL. The role of potential mediators in racial inequalities in tooth loss: the Pro-Saude study. Community Dent Oral Epidemiol 2013; 41:509-16.

13. Jamieson LM, Steffens M, Paradies YC. Associations between discrimination and dental visiting behaviours in an Aboriginal Australian birth cohort. Aust N Z J Public Health 2013; 37:92-3.

14. Calvasina P, Muntaner C, Quinonez C. The deterioration of Canadian immigrants' oral health: analysis of the Longitudinal Survey of Immigrants to Canada. Community Dent Oral Epidemiol 2015; 43:424-32. 
15. Bastos JL, Celeste RK, Paradies YC. Racial inequalities in oral health. J Dent Res 2018; 97:878-86.

16. Noro LR, Roncalli AG, Mendes Junior FI, de Lima KC, Teixeira AK. Toothache and social and economic conditions among adolescents in Northeastern Brazil. Ciênc Saúde Colet 2014; 19:105-13.

17. Instituto Brasileiro de Geografia e Estatística. Pesquisa Nacional de Saúde do Escolar 2015 Rio de Janeiro: Instituto Brasileiro de Geografia e Estatística; 2016.

18. Instituto Brasileiro de Geografia e Estatística. Pesquisa Nacional de Saúde do Escolar 2009. Rio de Janeiro: Instituto Brasileiro de Geografia e Estatística; 2010.

19. Instituto Brasileiro de Geografia e Estatística. Pesquisa Nacional de Saúde do Escolar 2012. Rio de Janeiro: Instituto Brasileiro de Geografia e Estatística; 2013.

20. Petruccelli JL, Saboia AL. Características étnico-raciais da população. Classificações e identidades. Rio de Janeiro: Instituto Brasileiro de Geografia e Estatística; 2013.

21. Santos RV, Fry PH, Monteiro S, Maio MC, Rodrigues JC, Bastos-Rodrigues L, et al. Color, race, and genomic ancestry in Brazil: dialogues between anthropology and genetics. Curr Anthropol 2009; 50:787-819.

22. Lwanga S, Tye $\mathrm{C}$, Ayeni $\mathrm{O}$. Teaching health statistics: lesson and seminar outlines. Geneva: World Health Organization; 1999.

23. Barros AJ, Victora CG. Measuring coverage in $\mathrm{MNCH}$ : determining and interpreting inequalities in coverage of maternal, newborn, and child health interventions. PLoS Med 2013; 10:e1001390.

24. Harper S, Lynch J. Methods for measuring cancer disparities: using data relevant to healthy people 2010: cancer-related objectives. https://seer.cancer.gov/archive/publications/ disparities/measuring_disparities (accessed on 15/Feb/2020).

25. Silva I, Restrepo-Mendez MC, Costa JC, Ewerling F, Hellwig F, Ferreira LZ, et al. Measurement of social inequalities in health: concepts and methodological approaches in the Brazilian context. Epidemiol Serv Saúde 2018; 27:e000100017.

26. Mackenbach JP, Kunst AE. Measuring the magnitude of socio-economic inequalities in health: an overview of available measures illustrated with two examples from Europe. Soc Sci Med 1997; 44:757-71.

27. Guskuma RC, Lages VA, Hafner MB, RandoMeirelles MPM, Cypriano S, Sousa M, et al. Factors associated with the prevalence and intensity of dental pain in children in the municipalities of the Campinas Region, São Paulo. Rev Paul Pediatr 2017; 35:322-30.

28. Goes PS, Watt RG, Hardy R, Sheiham A. Impacts of dental pain on daily activities of adolescents aged 14-15 years and their families. Acta Odontol Scand 2008; 66:7-12.
29. Matos DL, Lima-Costa MFF, Guerra HL, Marcenes W. Projeto Bambuí: estudo de base populacional dos fatores associados com o uso regular de serviços odontológicos em adultos. Cad Saúde Pública 2001; 17:661-8.

30. Camargo MBJ, Dumith SC, Barros AJD. Uso regular de serviços odontológicos entre adultos: padrões de utilização e tipos de serviços. Cad Saúde Pública 2009; 25:1894-906.

31. Lucas SD, Mattos FF, Melo JA, Vasconcelos M, Abreu MH, Ferreira NE. Uso de metáforas para expressar a dor de dente: um estudo na área de antropologia da saúde. Ciênc Saúde Colet 2014; 19:1933-42.

32. Amaral Junior OL, Menegazzo GR, Fagundes MLB, de Sousa JL, Torres L, Giordani J. Perceived discrimination in health services and preventive dental attendance in Brazilian adults. Community Dent Oral Epidemiol 2020; 48:533-9.

33. Chisini LA, Noronha TG, Ramos EC, Dos Santos-Junior RB, Sampaio KH, Faria ESAL, et al. Does the skin color of patients influence the treatment decision-making of dentists? A randomized questionnaire-based study. Clin Oral Investig 2019; 23:1023-30.

34. Chisini LA, Collares K, Bastos JLD, Peres KG, Peres MA, Horta BL, et al. Skin color affect the replacement of amalgam for composite in posterior restorations: a birth-cohort study. Braz Oral Res 2019; 33:e54.

35. Ciconello A. The challenge of eliminating racism in Brazil: the new institutional framework for fighting racial inequality. Nairobi: Oxfam International; 2008.

36. Pereira A, Araújo M. Race, history, and education in Brazil and in Portugal: challenges and perspectives. Educação e Realidade 2017; 42:139-60.

37. Martine J. "Worthy of freedom": abolitionist discourse on slavery, freedom, and imprisonment in late nineteenth-century Brazil. Journal of Social History 2019; 52:677-704.

38. Valente R, Berry B. Residential segregation by skin color: Brazil revisited. Lat Am Res Rev 2020; 55:207-26.

39. Fernandes G. Is the Brazilian tale of peaceful racial coexistence true? Some evidence from school segregation and the huge racial gap in the largest Brazilian city. World Dev 2017; 98:179-94.

40. Bastos FI. Structural violence in the context of drug policy and initiatives aiming to reduce drug-related harm in contemporary Brazil: a review. Subst Use Misuse 2012; 47:1603-10.

41. Faerstein E, Chor D, Werneck GL, Lopes CS, Kaplan G. Race and perceived racism, education, and hypertension among Brazilian civil servants: the Pro-Saude Study. Rev Bras Epidemiol 2014; 17 Suppl 2:81-7. 
42. Santana V, Almeida-Filho N, Roberts R, Cooper SP. Skin colour, perception of racism and depression among adolescents in urban Brazil. Child Adolesc Ment Health 2007; 12:125-31.

43. Bonilla-Silva E. Rethinking racism: toward a structural interpretation. Am Sociol Rev 1997; 62:465-80.

44. Bonilla-Silva E, Forman T. "I am not a racist but...”: mapping white college students' racial ideology in the USA. Discourse \& Society 2000; 11:50-85.

45. Bonilla-Silva E. From bi-racial to tri-racial: towards a new system of racial stratification in the USA. Ethn Racial Stud 2004; 27:931-50.

46. Antunes J. Intervenções em saúde pública e seu impacto nas desigualdades sociais em saúde. Tempo Social 2015;27:161-75.

47. Silveira ADF, Moyses SJ, Kusma SZ, Moyses ST. Potential effectiveness of strategies to promote oral health in primary health care: comparative study among Brazilian capitals and regions. Rev Bras Epidemiol 2016; 19:851-65.
48. Frias AC, Antunes JL, Junqueira SR, Narvai PC. Determinantes individuais e contextuais da prevalência de cárie dentária não tratada no Brasil. Rev Panam Salud Pública 2007; 22:27985.

49. Vettore MV, Ahmad SFH, Machuca C, Fontanini H. Socio-economic status, social support, social network, dental status, and oral health reported outcomes in adolescents. Eur J Oral Sci 2019; 127:139-46.

50. Freire MC, Jordão LM, Malta DC, Andrade SS, Peres MA. Socioeconomic inequalities and changes in oral health behaviors among Brazilian adolescents from 2009 to 2012. Rev Saúde Pública 2015; 49:50.

51. Dao TT, LeResche L. Gender differences in pain. J Orofac Pain 2000; 14:169-84.

52. Lukacs JR. Sex differences in dental caries experience: clinical evidence, complex etiology. Clin Oral Investig 2011; 15:649-56. 


\section{Resumo}

O estudo teve dois objetivos: (a) investigar as desigualdades raciais enquanto uma dimensão específica que afeta a prevalência de dor de dente em adolescentes brasileiros, $e(b)$ analisar as variações regionais na prevalência de dor de dente. $O$ estudo transversal usou dados da Pesquisa Nacional de Saúde do Escolar (PeNSE), realizada com adolescentes em 2009, 2012 e 2015. Dor de dente foi avaliada com a pergunta: "Nos últimos seis meses, você teve dor de dente?”. As principais exposições foram raça/cor e macrorregiões brasileiras, usadas para avaliar as desigualdades relacionadas ao desfecho. Sexo, idade, tipo de escola e escolaridade materna foram as covariáveis utilizadas. A significância estatística das tendências na prevalência de dor de dente foi testada com regressão linear. As análises foram realizadas com o programa estatístico Stata 13.0, usando o comando svy. A prevalência padrão de dor de dente foi 18,8\%, 21,1\% e 23,7\%, com uma tendência crescente ao longo do tempo $(p<0,001)$. Foram observadas desigualdades absolutas na prevalência de dor de dente de acordo com raça e macrorregião. A prevalência mais alta esteve associada ao sexo feminino, raça não-branca, escola pública e Região Norte do país. Os indices de desigualdade aumentaram no grupo de meninas negras, refletidos em um aumento na prevalência de dor de dente em meninas cujas mães tinham menos escolaridade. A prevalência de dor de dente em adolescentes brasileiros aumentou ao longo do tempo, e as desigualdades em relação à dor de dente persistiram nas populações marginalizadas e de acordo com a região do país.

Odontalgia; Adolescente; Monitoramento das Desigualdades em Saúde; Saúde Bucal

\section{Resumen}

El objetivo del estudio fue doble: (a) investigar las desigualdades raciales, como una dimensión específica que afecta al dolor dental, en adolescentes brasileños; e (b) investigar las variaciones regionales del dolor dental. Este estudio transversal usó datos de la Encuesta Nacional de Salud del Escolar (PeNSE), llevada a cabo con adolescentes en 2009, 2012 y 2015. El dolor dental fue evaluado por la pregunta: "En los últimos seis meses, ¿sufriste dolor dental?”. Los principales factores de exposición fueron raza y regiones brasileñas, y se usaron para evaluar las desigualdades relacionadas con los resultados. Sexo, edad, tipo de escuela y educación maternal fueron las covariables usadas. La significación estadística de las tendencias en el dolor dental fue probada usando regresión lineal. El análisis se realizó con el paquete estadístico Stata 13.0, usando el comando svy. El estándar de prevalencia de dolor dental fue 18,8\%, 21, 1\% y 23,7\%, con tendencia a aumentar a lo largo del tiempo $(p<0.001)$. Se observaron desigualdades absolutas en el dolor dental, relacionadas con raza y regiones. Se encontró una prevalencia más alta en chicas, de raza no blanca, escuelas públicas y Región del Norte. Los indices de desigualdades se incrementaron en el grupo de chicas negras, en detrimento de un incremento en la prevalencia del dolor dental en chicas cuyas madres contaban con menos educación formal. Se observó que la prevalencia de dolor dental en adolescentes brasileñas se incrementó a lo largo del tiempo y las desigualdades, respecto al dolor dental, continuaron manteniéndose en el tiempo en poblaciones marginalizadas $y$ acordes con determinadas regiones brasileñas.

Odontalgia; Adolescente; Monitoreo de las Desigualdades en Salud; Salud Bucal
Submitted on 06/May/2020

Final version resubmitted on 06/Sep/2020

Approved on 18/Sep/2020 